\title{
Organizational culture, authentic leadership and quality improvement in Canadian healthcare facilities
}

\author{
Cultura organizacional, liderança autêntica e melhoria da qualidade em instituições de saúde canadenses \\ Cultura organizacional, liderazgo auténtico y mejorías en la calidade de instituciones de salud canadienses
}

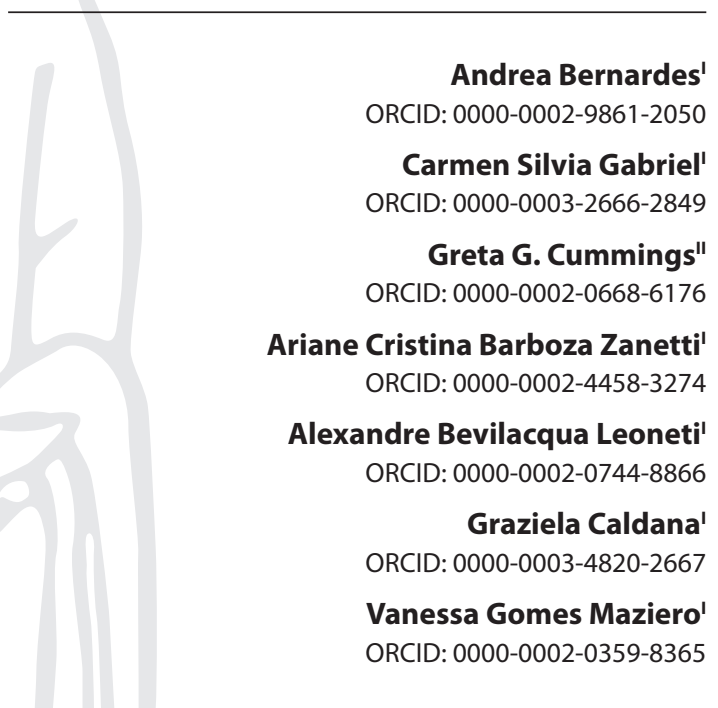

'Universidade de São Paulo. Ribeirão Preto, São Paulo, Brazil. "University of Alberta, Faculty of Nursing. Edmonton-Alberta, Canada.

How to cite this article: Bernardes A, Gabriel CS, Cummings GG, Zanetti ACB, Leoneti $A B$, Caldana $G$, et al. Organizational culture, authentic leadership and quality improvement in Canadian healthcare facilities. Rev Bras Enferm. 2020;73(Suppl 5):e20190732. doi: http://dx.doi.org/10.1590/0034-7167-2019-0732

Corresponding author: Andrea Bernardes

E-mail: andreab@eerp.usp.br

EDITOR IN CHIEF: Antonio José de Almeida Filho ASSOCIATE EDITOR: Maria Isabel Salamanca

Submission: 10-15-2019

Approval: 06-10-2020

\section{ABSTRACT}

Objective: To investigate relationships among flexible and hierarchical organizational cultures, quality improvement domains, and authentic leadership competencies in Canadian healthcare facilities. Method: Observational cross-sectional study conducted in Alberta, Canada. Nurse managers $(n=226)$ completed a survey including validated measures of organizational culture, quality improvement and authentic leadership. Data were analyzed using descriptive statistics, Spearman's correlation coefficient and Chi-squared test $(p<0.05)$. Results: Quality improvement through accreditation is related to organizational culture and authentic leadership. We saw a propensity for participants who reported working in a more flexible culture also reported greater quality improvement implementation and authentic leadership practices. Conclusion: This study assessed and reported the relationships between flexible organizational cultures, quality improvement through the accreditation process, and authentic leadership practices of healthcare managers. Flexible organizational cultures influence the adoption of authentic leadership, participatory management model and also improves quality.

Descriptors: Healthcare Quality Assessment; Leadership; Accreditation; Organizational Culture; Nursing.

\section{RESUMO}

Objetivo: Investigar as relações entre culturas organizacionais flexíveis e hierárquicas, domínios de melhoria da qualidade e competências da liderança autêntica em instituições de saúde canadenses. Método: Estudo observacional transversal realizado em Alberta, Canadá. Os gerentes de enfermagem $(n=226)$ responderam a um questionário validado sobre cultura organizacional, melhoria da qualidade e liderança autêntica. Os dados foram analisados por estatística descritiva, coeficiente de correlação de Spearman e teste Qui-quadrado $(p<0,05)$. Resultados: A melhoria da qualidade alcançada por meio da acreditação está relacionada à cultura organizacional adotada e à liderança autêntica. Participantes que relataram trabalhar em uma cultura flexível, também relataram maior investimento na melhoria da qualidade e práticas de liderança autênticas. Conclusão: Este estudo avaliou as relações entre culturas organizacionais flexíveis, melhoria da qualidade por meio da acreditação e práticas autênticas de liderança dos gerentes de enfermagem. Culturas organizacionais flexíveis influenciam a adoção da liderança autêntica, modelo de gestão participativo e melhoria da qualidade. Descritores: Garantia da Qualidade dos Cuidados de Saúde; Liderança; Acreditação; Cultura Organizacional; Enfermagem.

\section{RESUMEN}

Objetivo: investigar las relaciones entre culturas organizacionales flexibles y jerárquicas, los dominios de mejoría de calidad, y las competencias del liderazgo auténtico en las instituciones canadienses de cuidado a la salud. Método: estudio observacional trasversal conducido en Alberta, Canadá. Enfermeras administradoras $(n=226)$ respondieron a una encuesta incluyendo medidas validadas de cultura organizacional, mejoría de calidad, y liderazgo auténtico. Se analizó a los datos por medio de estadística descriptiva, de la correlación de Spearman, y de la prueba de ji-cuadrado $(p<0,05)$. Resultados: la mejoría de la calidad por medio de acreditación está relacionada a la cultura organizacional y al liderazgo auténtico. Hemos visto una tendencia según la cual los participantes que dijeron trabajar en una cultura más flexible también expresaron que hubo una implantación mayor de mejorías y de prácticas de liderazgo auténtico. Conclusión: ese estudio verificó y relató las relaciones entre culturas organizacionales flexibles, mejorías de calidad por medio de procesos de acreditación y prácticas de liderazgo auténtico de administradoras de atención a la salud. Culturas organizacionales flexibles influencian en la adopción de un liderazgo auténtico, de un modelo de administración participativo, además de mejoraren la calidad.

Descriptores: Garantía de la Calidad de Atención de Salud; Liderazgo; Acreditación; Cultura Organizacional; Enfermería. 


\section{INTRODUCTION}

The improvement of hospital quality has been widely emphasized by healthcare systems, which seek to offer quality care to patients. Therefore, the implementation of management mechanisms aimed at improving quality are essential for the health sector future.

Worldwide, health services have adopted the accreditation system as a tool for quality improvement because the goals of the program include assessment of safety, lower mortality rates, systematic use of quality tools, development of a culture of quality through the participation of professionals in the process, patient satisfaction, attainment of external recognition ${ }^{(1)}$ (Falstie-Jensen et al., 2015; Grepperud, 2015). Despite the significant growth of accreditation programs, knowing whether and how these programs have affected the quality of healthcare services has been a challenge for certification agencies, governments, society, and healthcare services $^{(2)}$ (Alkhenizan \& Shaw, 2011). Effective organizational capabilities, such as leadership, management model and culture, are essential components of quality improvement in healthcare facilities and work as the catalysts for accreditation programs $s^{(3)}$.

The existing organizational culture and management systems that emphasize formal and vertical structures no longer respond to the expectations of managers, workers, and especially patients ${ }^{(4)}$. Thus, the emergence of contemporary structures and management models have brought about a radical change in health work organizations. The consolidation of participative and democratic processes that stimulate team integration refers to a more cooperative and integrated work space, highlighting communication, trust, participation and autonomy in the process of choosing their leaders, demonstrating a greater investment in social capital of organizations ${ }^{(5)}$.

More participatory management methods that stimulate discussion environment and diagnosis of the organizational situation are needed ${ }^{(6)}$, so research on participatory models is carried out in the development of leadership. Studies have shown that leadership programs such as learning, mentoring, and coaching enhance individuals in developing leadership skills ${ }^{(7-8)}$. Thus, participatory models can help leaders to socially construct a new shared vision within health institutions ${ }^{(9)}$.

Therefore, organizational culture and the management model adopted by the institution are strongly related, which means that more traditional management models lead to hierarchical control and organizational values of control, stiff competition and individualism ${ }^{(10)}$.

\section{OBJECTIVE}

To investigate relationships among flexible and hierarchical organizational cultures, quality improvement domains, and authentic leadership competencies in Canadian healthcare facilities.

\section{METHOD}

\section{Ethical aspects}

The recruitment of nurse managers was done through the College and Association of Registered Nurses of Alberta (CARNA). To preserve the participants' anonymity, CARNA sent a recruitment letter explaining the details of the study, the Consent Form and the questionnaire. Ethical approval was provided by the Health Research Ethics Board of the University of Alberta (Study ID Pro00038738).

\section{Design, location and period}

This is a cross-sectional observational study with a quantitative data approach, which measures authentic leadership, perceived implementation of quality improvement (decision-making, safety, human resources, strategic quality planning, quality results, and customer satisfaction), and organizational culture in Canadian healthcare facilities, from the perspective of nurse managers from Alberta, Canada. Data collection was performed between July and September 2015.

\section{Population and sample; inclusion and exclusion criteria}

All nurses occupying manager positions (such as directors, patient care managers, unit managers, coordinators) working in healthcare facilities in Alberta who had consented to be contacted for research by CARNA $(n=1606)$ were invited to participate in this study. These nurse managers worked at Alberta Health Services (AHS), which is the first and largest province-wide, fully-integrated health system that delivers health services to over four million people living in Alberta $^{(11)}$. Those in temporary positions or who worked for less than year were excluded.

\section{Study protocol}

To test the theoretical assumptions, a questionnaire measuring organizational culture, leadership, quality improvement programs, and management model was used. To measure quality improvement and organizational culture, instrument "Quality Improvement Implementation Survey II" (QIIS) ${ }^{(12)}$ (Shortell et al., 1995) was used; and to measure authentic leadership, both versions (Self-assessed and Observer-assessed) of the "Authentic Leadership Questionnaire" (ALQ) were used ${ }^{(13)}$ were used (Walumbwa et al., 2007).

Quality Improvement Implementation Survey II (QIIS) is composed of 78 items divided into two parts. The first part refers to the organizational culture, consisting of 20 items in which the respondents must distribute 100 points among four organizational cultures (constant sum scale), depending on the relevance of the definitions. This led to four types of organizational culture - group culture (type A), developmental culture (type B), rational culture (type C), and hierarchical culture (type D); of these, type $A$ is the most flexible and type $D$ the least flexibility. The second part of the QIIS is related to measurement of the perception of quality improvement implementation processes, being constituted by 58 items and analyzed by a Likert scale. The QIIS subscales are: information and analysis, strategic quality planning, human resource utilization, quality management, quality results, customer satisfaction, and leadership for quality improvement. Cronbach Alpha for these subscales ranged between 0.93 to 0.79 in the original study ${ }^{(12)}$. 
Authentic Leadership Questionnaire (ALQ) is designed to measure components that comprise Authentic Leadership, using a 5 -point frequency scale where $1=\operatorname{Not}$ at all, to $5=$ Frequently, if not always. The ALQ subscales address the following questions: SelfAwareness: (how a person gives meaning to the world and how that process affects how she/he sees herself/himself over time); Transparency (the degree to which the leader reinforces a level of openness with others that provides them the opportunity to be forthcoming with their ideas, challenges, and opinions); Ethical/ Moral (the degree to which the leader sets a high standard for moral and ethical conduct); and Balanced processing (the degree to which the leader solicits sufficient opinions and viewpoints prior to making important decisions)(Walumbwa et al., 2007). Cronbach Alpha for these scales ranged between 0.92 to 0.72 in the original study ${ }^{(13)}$. Both versions of the ALQ described were answered by nurse managers: self-assessed version, where they evaluated themselves as authentic leaders, and observer-assessed version, where they evaluated their leaders.

Last, several questions, including demographic ones, were included in the instrument and tested for face and content validity ${ }^{(14)}$, in order to verify the management model. These questions were related to the adoption of a participatory/decentralized management model; the level of satisfaction with the current management model; involvement in the participatory management model; implementation of an accreditation program; participant involvement in the accreditation program; respondent's membership in quality council; and the level of satisfaction with the facility's accreditation processes. Participatory management models focus on decentralization of power and achievement of consensus, sharing decisions among staff, patients and other stakeholders of the organization, so that leadership is flexible and autonomy is shared by all involved ${ }^{(4)}$.

The ALQ used a Likert-type scale between 0 and 4 (five levels); while the QIIS used a Likert-type scale from 1=Strongly Disagree to $5=$ Strongly Agree and missing data were indicated with blank or 9 . The five levels scale from ALQ was adjusted from the range of 0-4 to the range of 1-5, similarly to the scale of QIIS. All data were cleaned and reviewed for missing data. Some participants chose 9, which means "don't know", or were left blank. As a result, an exclusion criterion was added. Cases with more than $10 \%$ missing data were identified and the amount of missing data per respondent were noted. Cases where respondents had five or more missing data $(9$ or blank) in these QIIS questions were excluded from the sample.

\section{Analysis of results and statistics}

Data analysis was performed based on descriptive and inferential statistics. The seven dimensions of the QIIS and the eight dimensions of ALQ were calculated by the aggregation of their respective questions by means of medians' calculation. These aggregated values were used to calculate their correlations with demographic data such as: participatory management model, involvement in the participatory management model, level of satisfaction with current management model, and level of satisfaction with accreditation process, using Spearman's correlation coefficient with significance of $p<0.05$. Internal consistency reliability was measured using Cronbach's alpha.
To examine whether differences in leadership and quality improvement scores varied by flexible or rigid organizational cultures, we divided the sample into two groups. We grouped data from participants according to their assessment of culture as more flexible ( $A$ and $B$ ) and more rigid ( $C$ and $D$ ). We calculated the frequency for each level of the five level scales of both QIIS and ALQ dimensions and checked the independence among the two groups using Chisquared test for independence with significance of $p<0.05$.

\section{RESULTS}

All participants were nurses occupying various managerial positions in the AHS, in Alberta, Canada. Of 1.606 invited participants, 255 (15.9\%) agreed to participate of the study. Twenty-four questionnaires were excluded from the sample because respondents had five or more missing data (9 or blank) in the QIIS, and $226(14.1 \%)$ usable questionnaires constituted the final sample. Most of the 226 participants worked in hospitals (58.8\%), in medium or large facilities (67.7\%), with more than 150 beds. Only $31.5 \%$ of respondents had some kind of post-graduate education, mostly (24.8\%) Master degrees. The sample was largely (91.6\%) composed of females (Table 1).

Table 1 - Characteristics of the sample $(n=226)$, Alberta, Canada, 2015

\begin{tabular}{lcc}
\hline Variables & $\mathbf{n}$ & $\%$ \\
\hline Gender & & \\
Male & 15 & 6.6 \\
Female & 207 & 91.6 \\
Missing & 4 & 1.8 \\
Position at the institution & & \\
Patient care manager & 86 & 38.1 \\
Unit manager & 68 & 30.1 \\
Director & 47 & 20.8 \\
Coordinator & 12 & 5.3 \\
Other & 11 & 4.8 \\
Missing & 2 & 0.9 \\
Education degree & & \\
Undergraduate Nursing & 148 & 65.4 \\
MBA & 11 & 4.9 \\
Master & 56 & 24.8 \\
PhD & 2 & 0.9 \\
Other & 2 & 0.9 \\
Missing & 7 & 3.1 \\
Type of institution & & \\
Public & 195 & 86.3 \\
Private & 29 & 12.8 \\
Missing & 2 & 0.9 \\
Bed size & & \\
49 beds or less & 37 & 16.4 \\
50-149 beds & 30 & 13.3 \\
150-499 beds & 79 & 35.0 \\
49 beds or less and 50-149 beds & 1 & 0.4 \\
More than 500 beds & 62 & 27.4 \\
Missing & 17 & 7.5 \\
Type of facility & 75 & 33.2 \\
General Hospital & 17 & 7.5 \\
Specialized Hospital & 41 & 18.1 \\
Teaching Hospital & 44 & 19.5 \\
Long Term Care & 26 & 11.5 \\
Community health center/primary care/home care & 5 & 2.2 \\
Administrative healthcare institutions & 14 & 6.2 \\
More than one facility & 3 & 1.4 \\
Other types of facilities & 1 & 0.4 \\
Missing & & \\
\hline & & \\
\hline
\end{tabular}


The mean age of respondents was 52.5 years $( \pm 8.0)$, ranging from 30 to 71 years, and the average professional experience was 28.2 years ( \pm 10.7$)$, with an average time in their respective institutions of 15.6 years $( \pm 10.3)$, including $8.4( \pm 6.7)$ years in a management position.

The majority (91.6\%) of healthcare facilities were accredited, usually with Accreditation Canada (89.8\%) and $60.2 \%$ of the respondents were satisfied or very satisfied with the program. Although $39.8 \%$ of them were members of the quality council, just $31.0 \%$ were totally involved with the accreditation process. Half of the respondents worked in institutions that had adopted or were in the process of adopting participatory management, and $36.3 \%$ of the respondents were partially or totally involved in the process, with more than $50 \%$ satisfied or very satisfied with the model. Respondents from health facilities with a group culture were most frequent ( $45.5 \%)$, followed by those in rational culture facilities (37.2\%). Based on the categorization of rigid or flexible cultures: $49.5 \%$ of participants worked in flexible cultures (A and B), and $50.5 \%$ of participants worked in rigid cultures (C and D) (Table 2).

In the preliminary descriptive, the medians of all quality improvement domains (QIIS) were "neither disagree or agree". However, analysis of the authentic leadership (ALQ) showed that the self-assessed scores were higher (fairly often) when compared to observer assessed (sometimes to fairly often). People who work in institutions with more flexible cultures scored higher on all dimensions of quality. Contrary, in self-assessed leadership, people evaluate themselves in a positive way, regardless of the quality domain. But they evaluate their leaders (observer-assessed version) better when they belong to an organization with a more flexible culture.

We selected the quality improvement domain subscales that presented distinct differences between the culture groups based on the significance of the Chi-squared test for independence (Table 3). Participants working in healthcare facilities with a more flexible culture ( $A$ and $B$ ) reported greater participation in strategic quality planning, human resource utilization, quality results, customer satisfaction, and leadership for quality improvement.

Managers who worked at health facilities with a more flexible culture perceived that there was more transparency, morality and ethics, and self-awareness related to leadership in the Observerassessed version of the ALQ (evaluating my leader), with a high concentration of the answers "fairly often" followed by "frequently, if not always". In the ALQ Self-assessed, the same domain was selected for comparison in both versions. This comparison revealed no significant differences between different cultures (Table 3), showing that participants evaluate themselves as good leaders independent of the culture group.

As shown in Table 4, only the variable "level of satisfaction with current management model" showed significant correlation with authentic leadership or QIIS subscales, specifically: human resource utilization, quality management, quality results, customer satisfaction, and leadership for quality improvement, all from QIIS; and transparency, moral/ethical, balanced processing, and self-awareness, all from ALQ (Observer-assessed). All Cronbach's alphas ranged from 0.70 to 0.95 , except for the ALQ Self-assessed, domain "Transparency," which was 0.57 .
Table 2 - Distribution of nurse managers according to accreditation, participatory management model and organizational culture characteristics, Alberta, Canada, 2015

\begin{tabular}{|c|c|c|}
\hline Variables & $\mathbf{n}$ & $\%$ \\
\hline \multicolumn{3}{|l|}{ Institutional accreditation } \\
\hline No & 5 & 2.2 \\
\hline In process & 11 & 4.9 \\
\hline Yes & 207 & 91.6 \\
\hline Missing & 3 & 1.3 \\
\hline \multicolumn{3}{|l|}{ Accreditation program } \\
\hline Accreditation Canada & 203 & 89.8 \\
\hline Other & 9 & 4.0 \\
\hline Missing & 14 & 6.2 \\
\hline \multicolumn{3}{|c|}{ Participant Involvement in the accreditation program } \\
\hline Not involved & 17 & 7.5 \\
\hline Rarely & 18 & 8.0 \\
\hline Partially & 114 & 50.4 \\
\hline Totally & 70 & 31.0 \\
\hline Missing & 7 & 3.1 \\
\hline \multicolumn{3}{|c|}{ Respondent's Membership in quality council } \\
\hline Yes & 90 & 39.8 \\
\hline No & 134 & 59.3 \\
\hline Missing & 2 & 0.9 \\
\hline \multicolumn{3}{|c|}{ Adoption of a participatory management model } \\
\hline No & 102 & 45.1 \\
\hline In process & 22 & 9.7 \\
\hline Yes & 90 & 39.8 \\
\hline Missing & 12 & 5.3 \\
\hline \multicolumn{3}{|c|}{ Involvement in the participatory management model } \\
\hline Not involved & 16 & 7.1 \\
\hline Rarely & 12 & 5.3 \\
\hline Partially & 50 & 22.1 \\
\hline Totally & 32 & 14.2 \\
\hline Missing & 116 & 51.3 \\
\hline \multicolumn{3}{|c|}{ Level of satisfaction with the current management model } \\
\hline Very dissatisfied & 11 & 4.9 \\
\hline Dissatisfied & 35 & 15.5 \\
\hline Satisfied & 91 & 40.3 \\
\hline Very satisfied & 27 & 11.9 \\
\hline Missing & 62 & 27.4 \\
\hline \multicolumn{3}{|c|}{ Level of satisfaction with accreditation process } \\
\hline Very dissatisfied & 2 & 0.9 \\
\hline Dissatisfied & 23 & 10.2 \\
\hline Satisfied & 105 & 46.5 \\
\hline Very satisfied & 31 & 13.7 \\
\hline Missing & 65 & 28.8 \\
\hline \multicolumn{3}{|l|}{ Organizational culture } \\
\hline Group (culture A) & 103 & 45.5 \\
\hline Developmental (culture B) & 9 & 4.0 \\
\hline Rational (culture C) & 84 & 37.2 \\
\hline Hierarchical (culture D) & 30 & 13.3 \\
\hline
\end{tabular}

Table 3 - Chi-squared test $\left(X^{2}\right)$ for independence of the instrument scores (Authentic Leadership Questionnaire and Quality Improvement Implementation Survey II), Alberta, Canada, 2015

\begin{tabular}{lc}
\hline Variables & $\mathbf{X}^{2}$ \\
\hline QIIS & \\
Information and analysis & $15.896^{*}$ \\
Strategic quality planning & $31.175^{*}$ \\
Human resource utilization & $51.142^{*}$ \\
Quality management & $19.553^{*}$ \\
Quality results & $35.251^{*}$ \\
Custumer satisfaction & $33.549^{*}$ \\
Leadership for quality improvement & $37.508^{*}$ \\
ALQ - As a leader I (Self-assessed) & \\
As leader_Transparency & 1.642 \\
As leader_Moral/Ethical & 0.538 \\
As leader_Balanced processing & 0.632 \\
As leader_Self-awareness & 6.691 \\
\hline
\end{tabular}




\begin{tabular}{lc}
\hline Variables & $\mathbf{X}^{\mathbf{2}}$ \\
\hline ALQ - My leader (Observer-assessed) & \\
My leader_Transparency & $22.210^{*}$ \\
My leader_Moral/Ethical & $25.062^{*}$ \\
My leader_Balanced processing & $11.961^{*}$ \\
My leader_Self-awareness & $23.416^{*}$ \\
\hline
\end{tabular}

Nota: *Independent at $p<0.05$. QIIS - Quality Improvement Implementation Survey II; ALQ - Authentic Leadership Questionnaire.

Table 4 - Spearman correlations ( $\rho$ ) between instrument scores (Authentic Leadership Questionnaire and Quality Improvement Implementation Survey II) and study variables, Alberta, Canada, 2015

\begin{tabular}{|c|c|c|c|c|c|}
\hline Variables & $\begin{array}{c}\text { Participatory } \\
\text { management } \\
\text { model }\end{array}$ & $\begin{array}{l}\text { Involvement } \\
\text { in the } \\
\text { participatory } \\
\text { management } \\
\text { model }\end{array}$ & $\begin{array}{c}\text { Level of } \\
\text { satisfaction } \\
\text { with current } \\
\text { management } \\
\text { model }\end{array}$ & $\begin{array}{c}\text { Level of } \\
\text { satisfaction } \\
\text { with } \\
\text { accreditation } \\
\text { process }\end{array}$ & $\begin{array}{c}\text { Cronbach's } \\
\text { alpha }\end{array}$ \\
\hline QIIS & $\rho$ & $\rho$ & $\rho$ & $\rho$ & \\
\hline Information and analysis & $0.15^{*}$ & 0.17 & $0.40^{*}$ & $0.34^{*}$ & 0.851 \\
\hline Strategic quality planning & $0.25^{*}$ & 0.17 & $0.40^{*}$ & $0.28^{*}$ & 0.798 \\
\hline Human resource utilization & $0.26^{*}$ & 0.17 & $0.52^{*}$ & $0.34^{*}$ & 0.857 \\
\hline Quality management & $0.17^{*}$ & 0.18 & $0.52^{*}$ & $0.37^{*}$ & 0.854 \\
\hline Quality results & $0.18^{*}$ & $0.20^{*}$ & $0.48^{*}$ & $0.41^{*}$ & 0.840 \\
\hline Customer satisfaction & $0.19^{*}$ & 0.14 & $0.46^{*}$ & $0.26^{*}$ & 0.890 \\
\hline $\begin{array}{l}\text { Leadership for quality } \\
\text { improvement }\end{array}$ & $0.27^{*}$ & $0.20^{*}$ & $0.57^{*}$ & $0.36^{*}$ & 0.954 \\
\hline \multicolumn{6}{|l|}{ ALQ - As a leader I (Self-assessed) } \\
\hline Transparency & $0.16^{*}$ & 0.07 & $0.18^{*}$ & $0.17^{*}$ & 0.572 \\
\hline Moral / Ethical & 0.12 & 0.07 & 0.11 & $0.18^{*}$ & 0.711 \\
\hline Balanced processing & $0.20^{*}$ & 0.08 & 0.09 & 0.10 & 0.603 \\
\hline Self-awareness & $0.22 *$ & 0.05 & 0.14 & 0.11 & 0.726 \\
\hline \multicolumn{6}{|l|}{ ALQ - My leader (Observer-assessed) } \\
\hline Transparency & $0.25^{*}$ & 0.12 & $0.55^{*}$ & $0.28 *$ & 0.853 \\
\hline Moral / Ethical & $0.19^{*}$ & 0.17 & $0.57^{*}$ & $0.25^{*}$ & 0.881 \\
\hline Balanced processing & $0.23^{*}$ & 0.17 & $0.53^{*}$ & 0.14 & 0.833 \\
\hline Self-awareness & $0.21^{*}$ & $0.21 *$ & $0.56^{*}$ & $0.25^{*}$ & 0.915 \\
\hline
\end{tabular}

\section{DISCUSSION}

This study found that quality improvement through the accreditation program can be related to organizational culture and authentic leadership in specific aspects: there is a propensity for participants who are engaged in a more flexible culture to present a more positive vision of some domains of quality improvement implementation. Also, there is a tendency for the leader to selfassess more positively (ALQ - Self-assessed) regardless of the type of culture. Still, in relation to Authentic Leadership (ALQ - Observerassessed) it was evident that there is a more positive evaluation of the nurse managers inserted in cultures classified as more flexible.

The group of participants in institutions with a more flexible organizational culture $(A B)$ differed from the group that had a predominantly hierarchical organizational culture (CD) in aspects that encompass the processes of implementing quality improvement in accreditation programs, and especially in the human dimension addressed by the QIIS instrument. Human dimensions are important because they increase individuals' engagement with accreditation and other quality activities; they foster the involvement of teams in promoting learning, overcoming organizational limitations, and improving services ${ }^{(15)}$ (Greenfield et al., 2011). Brazilian study carried out in the south of Parana State addresses that accreditation mediates better job satisfaction, especially in terms of professional status and organizational norms ${ }^{(16)}$.
On the other hand, the dimensions of structural components and use of institutional information to improve operational performance did not show the same contrast between cultures. This result suggests that congruence between organizational culture and structure may be less relevant to these domains, since structural components are, hypothetically and in the short term, more easily manageable than the values, leadership styles, language, procedures, and routines that define the organizational culture and characterize the institution as unique $^{(17-18)}$ (Sasaki et al., 2017; Wagner et al., 2014)(SASAKI et al., 2017; WAGNER et al., 2014).

Assessing organizational culture will provide insights into the perceptions of unit values to improve quality of care $^{(17)}$ (Sasaki et al., 2017). A more flexible culture was related to quality improvement ${ }^{(12)}$ (Shortell et al., 1995), being associated with a higher safety performance $^{(19)}$ (Profit et al., 2016). Our study examines all of these variables with the addition of authentic leadership.

Comparing QIIS subscales with distinct culture groups also demonstrated that participants engaged in health facilities with a more flexible culture ( $A$ and $B$ ) had a better evaluation of quality improvement related to strategic quality planning, human resource utilization, quality results, customer satisfaction, and leadership for quality improvement. In contrast, a 2009 study in several European countries found no association between the type of organizational culture and development of quality management in hospitals ${ }^{(18)}$ (Wagner et al., 2014). That study adopted a different instrument for measuring quality improvement, but using the same reference for classification of organizational cultures. Additionally, the sample comprised participants from various professions such as highest ranking nurses and physicians who specifically worked in the area of quality of institutions and senior management. In contrast, a large part of the sample of our study included participants occupying middle management positions, such as first line supervisors (68.8\%).

Regarding management models, $49.5 \%$ of the facilities adopted the participatory model and $45.1 \%$ a more traditional and vertical model. However, most participants (40.3\%), regardless of model, were satisfied with the current management model, and there was a significant correlation between satisfaction and Human resource utilization, Quality management, Quality results, Customer satisfaction, Leadership for quality improvement (QIIS instrument) and all domains of Observer-assessed version of the Authentic Leadership Questionnaire (ALQ). Thus, the largest portion of the domains that presented a statistically 
significant correlation were the human dimension of the process of implementing quality improvement.

With regard to the correlation between QIIS domains and perceived satisfaction with the institutional management model, the strongest association was with the active components of the quality improvement context. This suggests that nurse managers perceive the importance of adopting management practices aimed at optimizing performance and team productivity, valuing patient satisfaction. However, the hospital management system should be focused on the construction of education and culture in the hospital ${ }^{(20)}$. The positive correlations found between the domains of the ALQ (Observer-assessed) and satisfaction with the management model pointed to the success of health leadership practice, which indicates an increase in managers' capacity for reflection and greater political astuteness. Thus, there is evidence to suggest that satisfaction with the management model, from organizational knowledge, has influence on the advancement of leadership skills and objectives (WEAVER; DY; ROSEN, 2014)

Organizational culture is a reflection of values and dominant leadership theories which provide leaders with freedom to set goals, and to be more creative and innovative, leading to positive changes in the health organization ${ }^{(21)}$ (Srivastava, 2016). Authentic Leadership Theory, very desirable and effective for advancing the human factor and for achieving positive and lasting results by organizations $^{(13)}$ (Walumbwa et al., 2007), contributes to establishing more flexible cultures, as the current study shows. ALQ - Observerassessed indicated that evaluation of the leader is better when the health facility adopts a more flexible type of culture (group or developmental). This suggests an influence of the culture on the leadership style, or vice versa, especially regarding moral/ethical, transparency, and self-awareness domains. The moral/ethical domain emphasizes beliefs, values, and ethical decision-making as well as strategic leadership; transparency means to be genuine; and self-awareness is the ability to assess strengths and weaknesses of the team ${ }^{(22-23)}$ (Avolio et al., 2009; Hammer et al., 2013). There was no difference in the ALQ self-assessment, notwithstanding the culture, showing that participants evaluated themselves as good leaders in any situation. A similar bias was demonstrated in a study developed in Brazil, using the same leadership instrument, that concluded that when leaders are self-assessing, they consider themselves as participatory and interacting with others to perceive their needs ${ }^{(24)}$ (Carvalho et al., 2016).

The results of this study provided a beginning theoretical framing of the relationships among concepts that must be tested in subsequent research. We found that flexible organizational cultures influence the adoption of authentic leadership, participatory management model and also improves quality.

Strengths of this study are its strong theoretical base, and use of validated and reliable instruments. Choosing healthcare in Alberta, Canada, where almost all healthcare has implemented the accreditation program for several years and have now started to deploy new leadership models, provides an opportunity to compare different organizational cultures with representative samples.

\section{Limitations of the study}

This study has some limitations including the fact that the reality in Alberta is quite different from other countries where accreditation is still far from reaching all healthcare. Another limitation was that the cross-sectional study design does not permit strong conclusions about causality and also does not allow to assume the directionality of the associations found. To measure the implementation of quality improvement, only nursing managers were surveyed, whereas accessing other healthcare managers, regardless of the profession, may have provided a broad knowledge about quality management in organizations. Finally, the low response rate should be considered as an important limitation of the study.

\section{Contributions to the field of nursing, health or public policy}

Nurse managers play an important role in communicating with both nurses and senior executives, providing opportunity to enact authentic leadership and support quality improvement efforts. Our findings may assist nurse managers in implementing quality programs, based on evidence that authentic leadership and flexible organizational culture are the pathways to achieving success.

\section{CONCLUSION}

This study assessed and reported the relationships between flexible organizational cultures, quality improvement through the accreditation process, and authentic leadership practices of healthcare managers. We found that flexible organizational cultures influence the adoption of authentic leadership, participatory management model and also improves quality.

\section{FUNDING}

Research conducted with the support of the University of Sao Paulo Provost, process № 2012.1.25803.03.1.

\section{REFERENCES}

1. Grepperud S. Is the hospital decision to seek accreditation an effective one? Int J Health Plann Manage [Internet]. 2015 [cited 2019 Apr 28];30(1):E56-68. Available from: http://www.ncbi.nlm.nih.gov/pubmed/25470449

2. Alkhenizan A, Shaw C. Impact of accreditation on the quality of healthcare services: a systematic review of the literature. Ann Saudi Med [Internet]. 2011 [cited 2019 Apr 28];31(4):407-16. Available from: http://www.ncbi.nlm.nih.gov/pubmed/21808119

3. Glickman SW, Baggett KA, Krubert CG, Peterson ED, Schulman KA. Promoting quality: the health-care organization from a management perspective. Int J Qual Heal Care [Internet]. 2007 [cited 2019 Sep 21];19(6):341-8. Available from: https://academic.oup.com/intqhc/ article-lookup/doi/10.1093/intqhc/mzm047 
4. Bernardes A, Cummings GG, Gabriel CS, Évora YDM, Maziero VG, Coleman-Miller G. Implementation of a participatory management model: analysis from a political perspective. J Nurs Manag [Internet]. 2015 [cited 2019 Apr 28];23(7):888-97. Available from: http://www.ncbi.nlm. nih.gov/pubmed/24862294

5. Moura GMSS, Magalhães AMM, Dall'Agnol CM, Hoffmeister LV. A face oculta de um processo participativo para escolha de chefias de enfermagem. Texto Contexto Enferm. 2012;21(3):528-34. doi: 10.1590/S0104-07072012000300006

6. Bish M, Kenny A, Nay R. Using participatory action research to foster nurse leadership in Australian rural hospitals. Nurs Health Sci [Internet]. 2013 [cited 2019 Aug 2];15(3):286-91. Available from: http://www.ncbi.nlm.nih.gov/pubmed/23490407

7. Cummings GG, Spiers JA, Sharlow J, Germann P, Yurtseven O, Bhatti A. Worklife Improvement and Leadership Development study. Health Care Manage Rev [Internet]. 2013 [cited 2019 Aug 2];38(1):81-93. Available from: http://www.ncbi.nlm.nih.gov/pubmed/22314974

8. Mackoff BL, Glassman K, Budin W. Developing a Leadership Laboratory for Nurse Managers Based on Lived Experiences. JONA J Nurs Adm [Internet]. 2013 [cited 2019 Aug 2];43(9):447-54. Available from: http://www.ncbi.nlm.nih.gov/pubmed/23979035

9. Scholz G, Dewulf A, Pahl-Wostl C. An Analytical Framework of Social Learning Facilitated by Participatory Methods. Syst Pract Action Res [Internet]. 2014 [cited 2019 Aug 2];27(6):575-91. Available from: http://link.springer.com/10.1007/s11213-013-9310-z

10. Rocha FLR, Marziale MHP, Carvalho MC, Cardeal ISF, Campos MCT. The organizational culture of a Brazilian public hospital. Rev Esc Enferm USP. 2014;48(2):308-14. doi: 10.1590/S0080-6234201400002000016

11. Alberta Health Services (AHS). About AHS | Alberta Health Services [Internet]. 2019 [cited 2019 Aug 2]. Available from: http://www. albertahealthservices.ca/about/about.aspx

12. Shortell SM, O'Brien JL, Carman JM, Foster RW, Hughes EF, Boerstler H, et al. Assessing the impact of continuous quality improvement/total quality management: concept versus implementation. Health Serv Res [Internet]. 1995 [cited 2019 Feb 6];30(2):377-401. Available from: http://www.ncbi.nlm.nih.gov/pubmed/7782222

13. Walumbwa FO, Avolio BJ, Gardner WL, Wernsing TS, Peterson SJ. Authentic Leadership: Development and Validation of a TheoryBased Measure. J Manage [Internet]. 200826 [cited 2019 Apr 28];34(1):89-126. Available from: http://jom.sagepub.com/cgi/ doi/10.1177/0149206307308913

14. Pasquali L. Psychometrics. Rev da Esc Enferm da USP. 2009;43(spe):992-9. doi: 10.1590/S0080-62342009000500002

15. Greenfield D, Pawsey M, Braithwaite J. What motivates professionals to engage in the accreditation of healthcare organizations? Int J Qual Heal Care [Internet]. 2011 [cited 2019 Apr 27];23(1):8-14. Available from: http://www.ncbi.nlm.nih.gov/pubmed/21084322

16. Oliveira JLC, Magalhães AMM, Bernardes A, Haddad MCFL, Wolff LDG, Marcon SS, et al . Influência da Acreditação hospitalar na satisfação profissional da equipe de enfermagem: estudo de método misto. Rev Latino-Am Enfermagem. 2019;27:e3109. doi: 10.1590/1518-8345.2799.3109

17. Sasaki H, Yonemoto N, Mori R, Nishida T, Kusuda S, Nakayama T. Assessing archetypes of organizational culture based on the Competing Values Framework: the experimental use of the framework in Japanese neonatal intensive care units. Int J Qual Heal care J Int Soc Qual Heal Care [Internet]. 2017 [cited 2019 Apr 27];1-8. Available from: http://www.ncbi.nlm.nih.gov/pubmed/28371865

18. Wagner C, Groene O, Thompson CA, Dersarkissian M, Klazinga NS, Arah OA, et al. DUQuE quality management measures: associations between quality management at hospital and pathway levels. Int J Qual Heal Care [Internet]. 2014 [cited 2019 Jan 10];26(suppl 1):66-73. Available from: http://www.ncbi.nlm.nih.gov/pubmed/24615597

19. Profit J, Lee HC, Sharek PJ, Kan P, Nisbet CC, Thomas EJ, et al. Comparing NICU teamwork and safety climate across two commonly used survey instruments. BMJ Qual Saf [Internet]. 2016 [cited 2019 Apr 28];25(12):954-61. Available from: http://www.ncbi.nlm.nih.gov/ pubmed/26700545

20. Adibi H, Khalesi N, Ravaghi H, Jafari M, Jeddian A. Development of an effective risk management system in a teaching hospital. J Diabetes Metab Disord [Internet]. 2012 [cited 2019 Aug 2];11(1):15. Available from: http://www.ncbi.nlm.nih.gov/pubmed/23497710

21. Srivastava PC. Leadership styles in Western \& Eastern societies and its relation with organizational performance. Pranjana J Manag Aware. 2016;19(1):60-76. doi: 10.5958/0974-0945.2016.00006.6

22. Avolio BJ, Walumbwa FO, Weber TJ. Leadership: Current Theories, Research, and Future Directions. Annu Rev Psychol [Internet]. 2009 [cited 2019 Apr 28];60:421-49. Available from: http://communication-leadership-change.com/files/119516680.pdf

23. Hammer A, Arah OA, DerSarkissian M, Thompson CA, Mannion R, Wagner C, et al. The Relationship between Social Capital and Quality Management Systems in European Hospitals: A Quantitative Study. Cameron DW, editor. PLoS One [Internet]. 2013 [cited 2019 Jan 10];8(12):e85662. Available from: http://www.ncbi.nlm.nih.gov/pubmed/24392027

24. Carvalho AGF, Cunha ICKO, Balsanelli AP, Bernardes A. Liderança autêntica e perfil pessoal e profissional de enfermeiros. Acta Paul Enferm. 2016;29(6):618-25. doi: 10.1590/1982-0194201600087 